\title{
Frequency of gastrointestinal parasites in cats seen at the University of São Paulo Veterinary Hospital, Brazil
}

\author{
Frequência de parasitos gastrintestinais em gatos atendidos no Hospital Veterinário da \\ Universidade de São Paulo, Brasil \\ Solange Maria Gennari ${ }^{1 *}$; Juliana Isabel Giuli da Silva Ferreira ${ }^{1}$; Hilda Fátima de Jesus Pena ${ }^{1}$; \\ Marcelo Bahia Labruna ${ }^{1}$; Sérgio dos Santos Azevedo ${ }^{2}$

\begin{abstract}
${ }^{1}$ Departamento de Medicina Veterinária Preventiva e Saúde Animal, Faculdade de Medicina Veterinária e Zootecnia, Universidade de São Paulo - USP, São Paulo, SP, Brasil

${ }^{2}$ Unidade Acadêmica de Medicina Veterinária, Centro de Saúde e Tecnologia Rural, Universidade Federal de Campina Grande UFCG, Patos, PB, Brasil
\end{abstract}

Received July 21, 2016

Accepted Ausgust 23, 2016

\begin{abstract}
The frequency of gastrointestinal infections in 502 cats seen at the Veterinary Hospital of the University of São Paulo, SP, Brazil, between 2005 and 2014, was measured. The samples were analyzed using methods of flotation and sedimentation. The results were compared with those from studies published previously using fecal samples from the same hospital at different times. Associations between the frequency of positivity for each parasite and age, breed, sex, diarrhea and use of anthelmintic were investigated (chi-square or Fisher's exact tests). A partitioned chi-square test was used to compare different periods. Cryptosporidium spp., Giardia spp., Cystoisospora spp. and Sarcocystis spp. were the most common parasites, followed by Toxocara cati and Ancylostoma spp. Cryptosporidium spp. presented higher frequency in young cats and Sarcocystis spp. with the presence of diarrhea $(\mathrm{p}<0.05)$. Results from this study with previous periods showed that the frequencies of Cryptosporidium spp., Cystoisospora spp. and T. cati were lower $(\mathrm{p}<0.05)$ than those observed in previous periods. The frequencies of Giardia spp. and Ancylostoma spp. were similar to the results found in the preceding period and lower than the values found for the other periods $(\mathrm{p}<0.05)$. The reasons for these changes should be investigated.
\end{abstract}

Keywords: Cat, gastrointestinal parasites, São Paulo, Brazil.

\section{Resumo}

A frequência de infecçôes gastrintestinais foi avaliada em 502 gatos atendidos no Hospital Veterinário da Universidade de São Paulo, SP, Brasil, entre 2005 e 2014. As amostras foram analisadas utilizando-se os métodos de flutuação e sedimentação. Os resultados foram comparados com os de estudos previamente publicados com amostras de fezes oriundas do mesmo hospital, em momentos diferentes. As associaçóes entre a frequência de positividade para cada parasito e idade, raça, sexo, ocorrência de diarreia e uso de anti-helmínticos foram investigadas (teste de qui-quadrado ou teste exato de Fisher). Um teste de qui-quadrado estratificado foi utilizado para comparar os diferentes períodos (1991-1995; 1996-1999; 2000-2004 e 2005-2014). Cryptosporidium spp., Giardia spp., Cystoisospora spp. e Sarcocystis spp. foram os parasitos mais comuns parasitos, seguidos por Toxocara cati e Ancylostoma spp. Cryptosporidium spp. apresentou maior frequência em gatos jovens e Sarcocystis spp. em animais com diarreia $(\mathrm{p}<0,05)$. Comparação das frequências obtidas neste estudo com os de períodos anteriores mostrou que as frequências de Cryptosporidium spp., Cystoisospora spp. e T. cati foram menores $(\mathrm{p}<0,05)$ que as observadas nos períodos anteriores. As frequências de Giardia spp. e Ancylostoma spp. foram semelhantes $(p>0,05)$ aos resultados encontrados no período de 2000 a 2004 e menores do que os valores encontrados para os outros períodos $(\mathrm{p}<0,05)$. Os motivos dessas alteraçôes devem ser investigados.

Palavras-chave: Gatos, parasitas gastrintestinais, São Paulo, Brasil.

\footnotetext{
*Corresponding author: Solange Maria Gennari. Departamento de Medicina

Veterinária Preventiva e Saúde Animal, Faculdade de Medicina Veterinária e Zootecnia, Universidade de São Paulo - USP, Avenida Prof. Dr. Orlando Marques de Paiva, 87, Cidade Universitária, Butantã, CEP 05508-270, São Paulo, SP, Brasil. e-mail: sgennari@usp.br
} 


\section{Introduction}

Felines play an essential role in the epidemiology of gastrointestinal parasites causing zoonosis, including Ancylostoma tubaeforme, Ancylostoma braziliense, Toxocara cati, Dipylidium caninum and protozoa such as Giardia spp. and Cryptosporidium spp. (GENNARI et al., 2001; FUNADA et al., 2007).

According to the Brazilian Institute for Geography and Statistics (IBGE, 2015), there are 22.1 million domestic cats in Brazil, thus representing approximately 1.9 cats per household. However, in some regions of the country, studies on the prevalence of gastrointestinal parasites of cats are scarce or absent, and veterinarians have very little information for developing strategic control measures and treatments.

The aims of this study were to determine the frequency of gastrointestinal parasites in fecal samples from cats seen at a veterinary teaching hospital, in the metropolitan region of São Paulo, SP, Brazil, from 2005-2014, and compare this with results published previously (GENNARI et al., 1999, 2001; FUNADA et al., 2007), from the same diagnostic service since 1991.

\section{Materials and Methods}

\section{Animals}

The data used in the present study were obtained from single fecal samples from all cats examined for gastrointestinal parasites at the Parasitology Laboratory Service of the Veterinary Hospital (HOVET), University of São Paulo Veterinary School, São Paulo, SP, Brazil, from January 2005 to December 2014. The samples were collected by the owners, kept refrigerated and send to the laboratory within 12 hours after collection.

A total of 502 samples from domestic cats (i.e. with an owner) living in the metropolitan region of São Paulo were examined. Information relating to sex, breed (belonging or not belonging to a breed), age (< one year, $\geq$ one year), presence or absence of diarrhea and use of anthelmintics were available, but not for all the cat samples. Out of this total, it was known that 262 of the cats were male and 228 were female; 105 were young (< one year) and 340 were adults ( $\geq$ one year); 137 belonged to a breed and 349 did not belong to any defined breed; 170 presented diarrhea and 98 did not have diarrhea; and 148 had had anthelminthics administered previously and 87 had never used anthelminthics.

\section{Diagnostic techniques}

The routine diagnostic procedures used at the parasitological service consist of three methods: centrifugal sedimentation in water-ether (FERREIRA et al., 1962), flotation in sucrose solution $\left(\mathrm{d}=1.203 \mathrm{~g} / \mathrm{cm}^{3}\right)$ (OGASSAWARA \& BENASSI, 1980) and flotation in saturated $\mathrm{NaCl}$ solution. Dipylidium caninum was diagnosed based on the presence of proglottids in feces. All the methods were qualitative, and the results were expressed as presence of parasites.

\section{Statistical analyses}

The frequency of positive cats and respective binomial 95\% confidence intervals (CI) were calculated for each parasite. The associations between the frequencies of each parasite and the variables of age, breed, gender, occurrence of diarrhea and anthelmintic treatment were investigated using the chi-square or Fisher's exact tests (ZAR, 1999). A partitioned chi-square test was used to compare four periods (1991-1995; 1996-1999; 2000-2004; and 2005-2014) in relation to positivity for each parasite. $\mathrm{P}$ values $<0.05$ were considered significant. All the analyses were performed using the BioEstat software (AYRES et al., 2007), version 5.03 .

\section{Results}

A total of 502 cats were examined, and the overall infection occurrence rate was $18.1 \%\left[\mathrm{CI}_{95 \%}: 15.0-21.7 \%\right.$; 91/502]. Mixed infection was presented by $4.4 \%\left[\mathrm{CI}_{95 \%}: 2.1-5.4 \% ; 17 / 502\right]$ of the animals examined, i.e. $18.7 \%$ (17/91) of the positive samples. The most frequent associations of infection were Giardia spp. and Cryptosporidium spp. (3/502) and Giardia spp., Cryptosporidium spp. and Cystoisospora spp. (3/502).

The protozoa Cryptosporidium spp., Giardia spp. and Cystoisospora spp. were the most common parasitic agents infecting the cats, with occurrence rates (with $95 \% \mathrm{CI}$ in brackets) of $5.9 \%$ [4.2; 8.4\%], 5.2\% [3.4; 7.5\%] and 4.6\% [3.1; 6.8\%], respectively. The nematodes with highest frequencies were Toxocara cati and Ancylostoma spp., respectively with $2.2 \%[1.2 ; 3.9 \%]$ and $1.4 \%$ [0.7; 2.9\%]. At lower positivity rates, protozoa of the genera Sarcocystis spp (7/502) and Chilomastix spp. (1/502) and the helminths Platynosomum spp. (4/502), Toxascaris leonina (2/502), and Dipylidium caninum (2/502) were also found. Table 1 presents the frequencies of cats positive for each parasite infection.

Table 2 presents the associations between each parasite and the variables analyzed. Cats aged less than one year and cats with diarrhea were associated with parasite infection $(\mathrm{p}<0.05)$.

Table 1. Frequency of occurrence (with 95\% CI) of gastrointestinal infection in fecal samples from 502 cats in the metropolitan region of São Paulo, according to parasite genus and species.

\begin{tabular}{lccc}
\hline \multirow{2}{*}{\multicolumn{1}{c}{ Parasites }} & \multicolumn{3}{c}{ Positive cats } \\
\cline { 2 - 4 } & Number & Occurrence (\%) & CI $_{95 \%}[\%]$ \\
\hline Helminths & & & \\
Toxocara cati & 11 & 2.2 & {$[1.2 ; 3.9]$} \\
Ancylostoma spp. & 7 & 1.4 & {$[0.7 ; 2.9]$} \\
Platynosomum spp. & 4 & 0.8 & {$[0.3 ; 2.0]$} \\
Toxascaris leonina & 2 & 0.4 & {$[0.1 ; 1.4]$} \\
Dipylidium caninum & 2 & 0.4 & {$[0.1 ; 1.4]$} \\
Protozoa & & & \\
Cryptosporidium spp. & 30 & 5.9 & {$[4.2 ; 8.4]$} \\
Giardia spp. & 26 & 5.2 & {$[3.4 ; 7.5]$} \\
Cystoisospora spp. & 23 & 4.6 & {$[3.1 ; 6.8]$} \\
Sarcocystis spp. & 7 & 1.4 & {$[0.7 ; 2.9]$} \\
Chilomastix spp. & 1 & 0.2 & {$[0.04 ; 1.1]$} \\
\hline
\end{tabular}


When the parasites were analyzed individually, Cryptosporidium spp. was associated with age, such that there was higher frequency in young cats $(\mathrm{p}<0.05)$, and Sarcocystis spp. with presence of diarrhea $(\mathrm{p}<0.05)$.

Table 3 shows the results regarding the most common nematodes and protozoa (T. cati, Ancylostoma spp., Giardia spp., Cryptosporidium spp. and Cystoisospora spp.) found in the present study and comparisons with values previously published by the same laboratory service (same techniques and cats also attended by HOVET), during different periods (1991-1995, 1996-1999 and 2000-2004). For T. cati, Cryptosporidium spp. and Cystoisospora spp., the frequency rates found for the latest period (2005-2014) were lower $(\mathrm{p}<0.05)$ than values observed in the previous periods. For Ancylostoma spp. and Giardia spp., the frequencies were similar ( $p>0.05$ ) to those of the preceding period (2000-2004) and lower $(\mathrm{p}<0.05)$ than the values found in the other periods analyzed (1991-1995 and 1996-1999).

\section{Discussion}

The cats used in the present study were client-owned cats under care at a university veterinary hospital. Therefore, the results represent this category of household cats, and comparisons with shelter or stray cat surveys should be made with caution. Previous studies on household, stray and shelter cats found significant lower occurrence in the group of owned animals (REMBIESA \& RICHARDSON, 2003; SERRA et al., 2003; MCGLADE et al., 2003; JOFFE et al., 2011). However, in spite of having an owner and a home, some of those cats were free-roaming. They were allowed to go outdoors and thus became more exposed to sources of infection. They therefore represent a reservoir of parasites that are potentially zoonotic to humans and other companion animals.

In this study, the most frequent parasites were Cryptosporidium spp. (30/502), Giardia spp. (26/502) and Cystoisospora spp. (23/502).

Table 2. Frequency (\%) of helminths and protozoan parasites in feces from 502 cats according to age, breed, sex, presence of diarrhea and use of anthelmintics. São Paulo, 2005-2014.

\begin{tabular}{|c|c|c|c|c|c|c|c|c|c|c|}
\hline \multirow{3}{*}{ Parasites } & \multicolumn{2}{|c|}{ Age } & \multicolumn{2}{|c|}{ Breed } & \multicolumn{2}{|c|}{ Sex } & \multicolumn{2}{|c|}{ Diarrhea } & \multicolumn{2}{|c|}{$\begin{array}{c}\text { Anthelmintic } \\
\text { treatment }\end{array}$} \\
\hline & $<1$ year & $\geq 1$ year & Pure & Mixed & Male & Female & No & Yes & No & Yes \\
\hline & \multicolumn{10}{|c|}{ No. positive (\%) } \\
\hline Total & $33(31.4)^{*}$ & $43(12.6)^{*}$ & $19(13.9)$ & $68(19.5)$ & $47(17.9)$ & $42(18.4)$ & $45(14.5)^{*}$ & $44(25.9)^{*}$ & $62(18.2)$ & $27(18.2)$ \\
\hline Mixed infection & $4(3.8)$ & $8(2.4)$ & $3(2.2)$ & $12(3.4)$ & $8(3.1)$ & $8(3.5)$ & $9(2.9)$ & $8(4.7)$ & $12(3.5)$ & $5(3.4)$ \\
\hline \multicolumn{11}{|l|}{ Helminths } \\
\hline Toxocara cati & $4(3.8)$ & $4(1.2)$ & $1(0.7)$ & $9(2.6)$ & $4(1.5)$ & $6(2.6)$ & $6(1.9)$ & $4(2.4)$ & $6(1.8)$ & $5(3.4)$ \\
\hline Ancylostoma spp. & $3(2.9)$ & $3(0.9)$ & $3(2.2)$ & $4(1.1)$ & $3(1.1)$ & $4(1.8)$ & $6(1.9)$ & $0(0)$ & $7(2.1)$ & $0(0)$ \\
\hline Toxascaris leonina & $0(0)$ & $1(0.3)$ & $1(0.7)$ & $0(0)$ & $2(0.8)$ & $0(0)$ & $2(0.6)$ & $0(0)$ & $2(0.6)$ & $0(0)$ \\
\hline Platynosomum spp. & $0(0)$ & $2(0.6)$ & $1(0.7)$ & $2(0.6)$ & $1(0.4)$ & $3(1.3)$ & $2(0.6)$ & $2(1.2)$ & $2(0.6)$ & $2(1.4)$ \\
\hline Dipylidium sp. & $0(0)$ & $1(0.3)$ & $0(0)$ & $1(0.3)$ & $1(0.4)$ & $0(0)$ & $1(0.3)$ & $1(0.6)$ & $1(0.3)$ & $1(0.7)$ \\
\hline \multicolumn{11}{|l|}{ Protozoa } \\
\hline Cryptosporidium spp. & $14(13.3)^{*}$ & $10(2.9)^{*}$ & $6(4.4)$ & $22(6.3)$ & $13(5)$ & $16(7)$ & $14(4.5)$ & $16(9.4)$ & $20(5.9)$ & $10(6.8)$ \\
\hline Giardia spp. & $9(8.6)$ & $13(3.8)$ & $3(2.2)$ & $23(6.6)$ & $15(5.7)$ & $11(4.8)$ & $12(3.9)$ & $14(8.2)$ & $18(5.3)$ & $7(4.7)$ \\
\hline Cystoisospora spp. & $7(6.7)$ & $14(4.1)$ & $5(3.6)$ & $18(5.2)$ & $12(4.6)$ & $11(4.8)$ & $11(3.5)$ & $12(7.1)$ & $15(4.4)$ & $8(5.4)$ \\
\hline Sarcocystis spp. & $0(0)$ & $7(2.1)$ & $2(1.5)$ & $5(1.4)$ & $5(1.9)$ & $2(0.9)$ & $1(0.3)^{*}$ & $6(3.5)^{*}$ & $6(1.8)$ & $0(0)$ \\
\hline Chilomastix spp. & $0(0)$ & $1(0.3)$ & $0(0)$ & $1(0.3)$ & $0(0)$ & $1(0.4)$ & $0(0)$ & $1(0.6)$ & $1(0.3)$ & $0(0)$ \\
\hline
\end{tabular}

$*(\mathrm{P}<0.05)$ between the categories within the same variable.

Table 3. Frequency of helminths and protozoa in fecal samples from cats seen at the Veterinary Hospital, University of São Paulo Veterinary School, São Paulo, SP, Brazil, from 1991 to 2014.

\begin{tabular}{|c|c|c|c|c|}
\hline \multirow{2}{*}{ Parasites } & \multicolumn{4}{|c|}{$\begin{array}{c}\text { Period } \\
\text { Positive (\%) }\end{array}$} \\
\hline & $\begin{array}{c}1991-1995^{1} \\
(\mathrm{n}=187)\end{array}$ & $\begin{array}{c}1996-1999^{2} \\
(\mathrm{n}=303)\end{array}$ & $\begin{array}{c}2000-2004^{3} \\
(n=372)\end{array}$ & $\begin{array}{c}2005-2014^{4} \\
(n=502)\end{array}$ \\
\hline \multicolumn{5}{|l|}{ Helminths } \\
\hline Toxocara cati & $64(34.2)^{\mathbf{a}}$ & $31(10.2)^{\mathbf{b}}$ & $20(6.1)^{\mathbf{b}}$ & $11(2.2)^{\mathrm{c}}$ \\
\hline Ancylostoma spp. & $25(13.4)^{a}$ & $12(3.9)^{\mathbf{b}}$ & $7(2.1)^{\mathbf{b c}}$ & $7(1.4)^{\mathrm{c}}$ \\
\hline \multicolumn{5}{|l|}{ Protozoa } \\
\hline Giardia spp. & $30(16.0)^{\mathbf{a}}$ & $44(14.5)^{\mathbf{a}}$ & $27(8.3)^{\mathbf{b}}$ & $26(5.2)^{\mathbf{b}}$ \\
\hline Cryptosporidium spp. & $27(14.4)^{\mathbf{a}}$ & $31(10.2)^{\mathbf{a}}$ & $37(11.3)^{\mathrm{a}}$ & $30(5.9)^{\mathbf{b}}$ \\
\hline Cystoisospora spp. & $72(38.5)^{\mathbf{a}}$ & $40(13.2)^{\mathbf{b}}$ & $27(8.3)^{\mathbf{c}}$ & $23(4.6)^{d}$ \\
\hline
\end{tabular}

Different letters in the same row indicate significant differences by the chi-square partitioned test (p<0.05). ${ }^{1}$ Gennari et al. (1999), ${ }^{2} \mathrm{Gennari}$ et al. (2001), ${ }^{3} \mathrm{Funada}$ et al. (2007), ${ }^{4}$ Present study, $\mathrm{n}=$ number of cats examined. 
After these three protozoa, the nematodes $T$. cati (11/502) and Ancylostoma spp. (7/502) were the next most frequent. With the exception of the results observed during the first period analyzed (1991-1995), in which T. cati was among the three most common parasites, over the last 20 years the protozoa Cryptosporidium spp., Giardia spp. and Cystoisospora spp. have presented the highest frequencies in cats seen at HOVET.

Infections with more than one parasite were not very frequent, accounting for only $4.4 \%$ of all the samples examined, and the most common multiple infections were also between protozoa (Giardia spp. and Cryptosporidium spp.; and Giardia spp., Cryptosporidium spp. and Cystoisospora spp., each in 3/502). This result deserves special attention from veterinarians, who often use anthelmintics as a preventive control measure, without fecal examination. Several commercial anthelmintics did not show any effectiveness against protozoan parasites.

Unlike what has been observed with ascarids in dogs, T. cati presents a low level of resistance to reinfection in older cats and can be found throughout the animals' lives (OVERGAAUW \& NEDERLAND, 1997). T. cati is often reported to be the most prevalent nematode in cats around the world, as observed in surveys conducted in the USA (NOLAN \& SMITH, 1995), (REMBIESA \& RICHARDSON, 2003), Mexico (MARTÍNEZ-BARBABOSA et al., 2003), Chile (LÓPEZ et al., 2006), Iran (SHARIF et al., 2007), Australia (PALMER et al., 2008), Canada (JOFFE et al., 2011), Germany (BARUTZKI \& SCHAPER, 2011), Egypt (KHALAFALLA, 2011), Italy (ZANZANI et al., 2014) and China (YANG \& LIANG, 2015). Also, in Brazil, T. cati was found to be the most prevalent helminth in cats in Rio Grande do Sul (LORENZINI et al., 2007; PIVOTO et al., 2013), Paraná (TESSEROLLI et al., 2005), Santa Catarina (STALLIVIERE et al., 2009) and the metropolitan region of São Paulo (GENNARI et al., 2001; RAGOZO et al., 2002; FUNADA et al., 2007).

Although parasites of the genus Uncinaria have already been observed in stray cats in the city of Rio de Janeiro (UCHÔA et al., 1998), there is no description of this hookworm in dogs or cats from São Paulo, and, in this study, all diagnosed hookworm eggs were classified as Ancylostoma spp.

In the present study, the second most frequent nematode was Ancylostoma spp., which is considered to be the most prevalent nematode in dogs in Brazil (reviewed by LABRUNA et al., 2006), and also the one with the highest prevalence in cats in some Brazilian regions (SERRA et al., 2003; LABARTHE et al., 2004; COELHO et al., 2009; RAMOS et al., 2013; MONTEIRO et al., 2016). However, in all surveys on cats in the metropolitan region of São Paulo (OGASSAWARA et al., 1986; GENNARI et al., 1999, 2001; RAGOZO et al., 2002; FUNADA et al., 2007) since 1986, Ancylostoma spp. has been the second most prevalent nematode, and in four of the five studies, T. cati occurrence was around three times higher than that of Ancylostoma spp., in both owned and shelter cats.

Platynosomum fastosum is a trematode that inhabits the hepatobiliary system of domestic and wild felids in tropical and subtropical regions (HEADLEY et al., 2011). In a retrospective study on cats seen at the University of Londrina Veterinary Hospital, in Paraná, Brazil, the most common pathological alterations associated with parasitism by $P$. fastosum were bile duct hypertrophy and adenomatous epithelial hyperplasia (HEADLEY et al., 2011).

In Brazil, pathological alterations due $P$. fastosum have also been described in cats in Bahia (SAMPAIO et al., 2006), São Paulo (XAVIER et al., 2007; CARREIRA et al., 2008) and Minas Gerais (VIEIRA et al., 2009). Compared with previous studies, in which this trematode was present with occurrence rates of $1.07 \%$ (GENNARI et al., 1999) and 0.3\% (FUNADA et al., 2007), the rate of $0.8 \%$ found in the present period is almost unchanged.

Dipylidium caninum has been found to be very prevalent in all studies in which the animals were necropsied, because the whole proglottid, i. e. the diagnostic stage, is seldom seen in feces. By means of fecal examination, Martinez-Carrasco et al. (2007) found $1 \%$ of the dogs examined were positive, whereas necropsies on the same population showed that this tapeworm was present in $47 \%$ of the dogs. Thus, the findings from the present study, which were obtained through fecal examination, are certainly underestimates.

The protozoa Cryptosporidium spp., Giardia spp. and Cystoisospora spp. presented very similar occurrence rates in this study and were the most common parasites found in these cats. Similar results were observed in the two previous periods compared: 1991-1999 (GENNARI et al., 1999, 2001) and 2000-2004 (FUNADA et al., 2007). However, the values found in the present period were lower $(\mathrm{p}<0.05)$ than those of the previous periods for Cryptosporidium spp. and Cystoisospora spp. For Giardia spp., although the occurrence rate was lower, this difference was not statistically significant. Ogassawara et al. (1986) and Ragozo et al. (2002), who both studied shelter cats in the metropolitan region of São Paulo, and Coelho et al. (2009), who studied shelter cats in Andradina, in the interior of the state of São Paulo, found that Cystoisospora spp. and Cryptosporidium spp. were the most frequent protozoan parasites. Their results thus confirm the present findings that cats in the state of São Paulo are frequently infected by these protozoa.

Cystoisospora spp. and Giardia spp. are also very frequent in cats in other regions of Brazil, with descriptions in Rio de Janeiro, Rio Grande do Sul, Paraná and Pernambuco (SERRA et al., 2003; TESSEROLLI et al., 2005; LORENZINI et al., 2007; MONTEIRO et al., 2016). According to Barutzki \& Schaper (2011), Giardia spp. is one of the most prevalent parasites of cats in some regions of Europe.

Although Cryptosporidium spp. showed an association with age, such that it was more frequently found in young cats (< one year of age), Cystoisospora spp. and Giardia spp. were present in cats of all ages, with similar occurrence. This result indicates that routine fecal examinations are also important for older cats, and that preventive use of anthelminthics, without previous stool examination, may be very useful for helminth control. However, these treatments may not be effective for protozoan parasites, since several formulations show efficacy only in relation to helminths. The cause of reduction in the occurrence of many of these parasites in recent years, especially helminths, is difficult to explain based only on data that is sent along with fecal samples. There can be many causes, from the more constant use of anthelmintics for all life of animals, lower contact of cats with sources of infections, keeping 
them with less access to the streets, to the greater consciousness of the owners of health care, among others.

Although infections by Cryptosporidium spp. usually cause diarrhea, especially in young animals, in this study there was no association between the presence of diarrhea and Cryptosporidium spp. infection. The same result was previously described by Lucas $\&$ Hagiwara (1997) among cats in the metropolitan region of São Paulo.

According to Dubey et al. (2016), cats are definitive hosts for numerous Sarcocystis species. In the present study, 3.5\% of the fecal samples presented Sarcocystis spp. sporocysts, and it was the only parasite in this study that presented an association with diarrhea ( $<<0.05)$, such that $0.3 \%$ and $3.5 \%$ of the cats without and with diarrhea, respectively, were positive for these species.

Information about the use of anthelmintics was available for 235 cats. Out of this total, 148 (63\%) had been administered anthelminthics previously and 87 (37\%) had never used anthelminthics. At least one third of the owners were uninformed about the importance of anthelmintic treatment and control of endoparasites in their animals.

The cats in the present study were infected by potentially zoonotic parasites such as Giardia spp., Cryptosporidium spp., T. cati and Ancylostoma spp. Cats have an important role in the homes on which they live, often sharing with their owners the same locations in the house. This study provides information for veterinarians to be able to implement control measures, thereby not only acting on pets, but also reducing the risk of parasite transmission.

\section{Acknowledgements}

S. M. Gennari, M. B. Labruna and S. S. Azevedo hold fellowships from the Brazilian funding agency CNPq. We would like to thanks Renato Caravieri for his technical support.

\section{References}

Ayres M, Ayres M Jr, Ayres DM, Santos AAS. BioEstat: aplicaçōes estatísticas nas áreas das ciências bio-médicas. 5th ed. Belém: Ong Mamiraua; 2007.364 p.

Barutzki D, Schaper R. Results of parasitological examinations of faecal samples from cats and dogs in Germany between 2003-2010. Parasitol Res 2011;109(S1 Suppl 1): 45-60. PMid:21739375. http://dx.doi. org/10.1007/s00436-011-2402-8.

Carreira VS, Vieira RFC, Machado GF, Luvizotto MCR. Feline cholangitis/ chonlangiohepatitis complex secondary to Platynosomum fastosum infection in a cat. Braz J Vet Parasitol 2008; 17(S1): 184-187.

Coelho WMD, Amarante AFT, Soutello RVG, Meireles MV, Bresciane KDS. Ocorrência de parasitos gastrintestinais em amostras fecais de felinos no município de Andradina, São Paulo. Braz J Vet Parasitol 2009; 18(2): 46-49. http://dx.doi.org/10.4322/rbpv.01802010.

Dubey JP, Calero-Bernal R, Rosenthal BM, Speer CA, Fayer R. Sarcocystis of animal and humans. 2nd ed. Boca Raton: CRC Press; 2016. 481 p.

Ferreira LF, Morteo RE, Silva JR. Padronização de técnicas para o exame parasitológico das fezes. J Bras Med 1962; 6(2): 241-257.
Funada MR, Pena HFJ, Soares RM, Amaku M, Gennari SM. Freqüência de parasitos gastrintestinais em cães e gatos atendidos em hospital-escola veterinário da cidade de São Paulo. Arq Bras Med Vet Zootec 2007; 59(5): 1338-1340. http://dx.doi.org/10.1590/S0102-09352007000500038.

Gennari SM, Kasai N, Pena HFJ, Cortez A. Ocorrência de protozoários e helmintos em amostras de fezes de cães e gatos da cidade de São Paulo. Braz J Vet Res Anim Sci 1999; 36(2): 87-91. http://dx.doi.org/10.1590/ S1413-95961999000200006.

Gennari SM, Pena HFJ, Blasques LS. Frequência de ocorrência de parasitos gastrintestinais em amostras de fezes de cáes e gatos da cidade de São Paulo. Vet News 2001; 8(52): 10-12.

Headley SA, Ferioli RB, Reis ACF, Bracarense APFRL. Platynosomum fastosum-induced infections in domestic shorthair cats: a retrospective study of seven cases. Braz J Vet Pathol 2011; 4: 227-234.

Instituto Brasileiro de Geografia e Estatística - IBGE. Pesquisa nacional de saúde 2013: acesso e utilizaçâo dos serviços de saúde, acidentes e violências: Brasil, grandes regióes e unidades da federação. Rio de Janeiro: IBGE; 2015. 100 p.

Joffe D, Van Niekerk D, Gagné F, Gilleard J, Kutz S, Lobingier R. The prevalence of intestinal parasites in dogs and cats in Calgary, Alberta. Can Vet J 2011; 52(12): 1323-1328. PMid:22654137.

Khalafalla RE. A survey study on gastrointestinal parasites of stray cats in Northern Region of Nile Delta, Egypt. PLoS One 2011; 6(7): e20283. PMid:21760884. http://dx.doi.org/10.1371/journal.pone.0020283.

Labarthe N, Serráo ML, Ferreira AMR, Almeida NKO, Guerrero J. A survey of gastrointestinal helminths in cats of the metropolitan region of Rio de Janeiro, Brazil. Vet Parasitol 2004; 123(1-2): 133-139. PMid:15265577. http://dx.doi.org/10.1016/j.vetpar.2004.06.002

Labruna MB, Pena HFJ, Souza SLP, Pinter A, Silva JCR, Ragozo AMA, et al. Prevalência de endoparasitas em cães da área urbana do município de Monte Negro, Rondônia. Arq Inst Biol (Sao Paulo) 2006; 73(2): 183-193.

López J, Abarca K, Paredes O, Inzunza E. Intestinal parasites in dogs and cats with gastrointestinal symptons in Santiago, Chile. Rev Med Chil 2006; 134(2): 193-200. http://dx.doi.org/10.4067/S0034-98872006000200009. PMid:16554927.

Lorenzini G, Tasca T, Carli GA. Prevalence of intestinal parasites in dogs and cats under veterinary care in Porto Alegre, Rio Grande do Sul, Brazil. Braz J Vet Res Anim Sci 2007; 44(2): 137-145. http://dx.doi. org/10.11606/issn.1678-4456.bjvras.2007.26652.

Lucas SRR, Hagiwara MK. Infecção por Cryptosporidium em gatos na cidade de São Paulo. R Bras Med Vet 1997; 19(1): 11-15.

Martínez-Barbabosa I, Tsuji OV, Cabello RR, Cárdenas EM, Chasin OA. The prevalence of Toxocara cati in domestic cats in Mexico city. Vet Parasitol 2003; 114(1): 43-49. PMid:12732465. http://dx.doi. org/10.1016/S0304-4017(03)00038-4.

Martínez-Carrasco C, Berriatua E, Garijo M, Martínez J, Alonso FD, Ybánez RR. Epidemiological study of non-systemic parasitism in dogs in southeast Mediterranean Spain assessed by coprological and postmortem examination. Zoonoses Public Health 2007; 54(5): 195-203. PMid:17542962. http://dx.doi.org/10.1111/j.1863-2378.2007.01047.x.

McGlade TR, Robertson ID, Elliot AD, Read C, Thompson RC. Gastrointestinal parasites of domestic cats in Perth, Western Australia. Vet Parasitol 2003; 117(4): 251-262. PMid:14637027. http://dx.doi. org/10.1016/j.vetpar.2003.08.010. 
Monteiro MFM, Ramos RAN, Calado AMC, Lima VFS, Ramos ICN, Tenório RFL, et al. Gastrointestinal parasites of cats in Brazil: frequency and zoonotic risk. BrazJ Vet Parasitol 2016; 25(2): 254-257. PMid:27096530. http://dx.doi.org/10.1590/S1984-29612016019.

Nolan TJ, Smith G. Time series analysis of the prevalence of endoparasitic infections in cats and dogs presented to a veterinary teaching hospital. Vet Parasitol 1995; 59(2): 87-96. PMid:7483240. http://dx.doi. org/10.1016/0304-4017(94)00742-U.

Ogassawara S, Benassi S, Larsson CE, Hagiwara MK. Prevalência de endoparasitas em gatos na cidade de São Paulo. Rev Fac Med Vet Zootec Univ S Paulo 1986; 23(1): 39-46. http://dx.doi.org/10.11606/issn.23183659.v23i1p39-46.

Ogassawara S, Benassi S. Infecção experimental de gatos com coração de bovino parasitado por Sarcocystis sp. Arq Inst Biol (Sao Paulo) 1980; 47(1-2): 27-32.

Overgaauw PAM, Nederland V. Aspects of Toxocara epidemiology: toxocarosis in dogs and cats. Crit Rev Microbiol 1997; 23(3): 233-251. PMid:9347222. http://dx.doi.org/10.3109/10408419709115138.

Palmer CS, Thompson RC, Traub RJ, Rees R, Robertson ID. National study of the gastrointestinal parasites of dogs and cats in Australia. Vet Parasitol 2008; 151(2-4): 181-190. PMid:18055119. http://dx.doi. org/10.1016/j.vetpar.2007.10.015.

Pivoto FL, Lopes LFD, Vogel FSF, Botton SA, Sangioni LA. Occurrence of gastrointestinal parasites and parasitism risk factors in domestic cats in Santa Maria, RS, Brazil. Cienc Rural 2013; 43(8): 1453-1458. http:// dx.doi.org/10.1590/S0103-84782013000800018.

Ragozo AMA, Muradian V, Silva JCR, Caravieri R, Amajoner VR, Magnabosco C, et al. Ocorrência de parasitos gastrintestinais em fezes de gatos das cidades de São Paulo e Guarulhos. BrazJ Vet Res Anim Sci 2002; 39(5): 244-246. http://dx.doi.org/10.1590/S1413-95962002000500005.

Ramos DGS, Scheremeta RGAC, Oliveira ACS, Sinkoc AL, Pacheco RC. Survey of helminth parasites of cats from the metropolitan area of Cuiabá, Mato Grosso, Brazil. Braz J Vet Parasitol 2013; 22(2): 201-206. PMid:23856737. http://dx.doi.org/10.1590/S1984-29612013000200040.

Rembiesa C, Richardson DJ. Helminth parasites of the house cat, Felis catus, in Connecticut, USA. Comp Parasitol 2003; 70(2): 115-119. http:// dx.doi.org/10.1654/1525-2647(2003)070[0115:HPOTHC]2.0.CO;2.

Sampaio MAS, Berlim CM, Angelim ALGL, Gondim LFP, Almeida MAO. Infecção natural pelo Platynosomum Looss 1907, em gato no município de Salvador, Bahia. Rev Bras Saúde Prod An 2006; 7(1): 1-6.
Serra CMB, Uchôa CMA, Coimbra RA. Exame parasitológico de fezes de gatos (Felis catus domesticus) domiciliados e errantes da Região Metropolitana do Rio de Janeiro, Brasil. Rev Soc Bras Med Trop 2003; 36(3): 331-334. PMid:12908032. http://dx.doi.org/10.1590/S003786822003000300003 .

Sharif M, Nasrolahei M, Ziapour SP, Gholami S, Ziaei H, Daryani A, et al. Toxocara cati infections in stray cats in northern Iran.J Helminthol 2007; 81(1): 63-66. PMid:17381869. http://dx.doi.org/10.1017/ S0022149X07214117.

Stalliviere FM, Bellato V, Souza AP, Sartor AA, Moura AB, Rosa LD. Ectoparasitos e helmintos intestinais em Felis catus domesticus da cidade de Lages, SC, Brasil e aspectos sócio-econômico e culturais das famílias dos proprietários dos animais. Braz J Vet Parasitol 2009; 18(4): 26-31. http://dx.doi.org/10.4322/rbpv.01804005.

Tesserolli GL, Fayzano L, Agottani JVB. Ocorrência de parasitas gastrintestinais em fezes de cães e gatos, Curitiba-PR. Rev Acad 2005; 3(4): 31-34.

Uchôa CMA, Peixoto CMS, Mattos DG Jr, Barcelos AV. Occurrence and identification of Uncinaria (Frohlish, 1789) (Nematoda: Ancylostomidae) parasites in stray cats (Felis catus) from Rio de Janeiro, Brazil. Braz J Vet Parasitol 1998; 7(2): 161-164.

Vieira ALS, Ecco R, Lima WS, Guedes RMC. Platynosomum fastosum infection in two cats in Belo Horizonte, Minas Gerais State, Brazil. Braz $J$ Vet Pathol 2009; 2(1): 45-48.

Xavier FG, Morato GS, Righi DA, Maiorka PC, Spinosa HS. Cystic liver disease related to high Platynosomum fastosum infection in a domestic cat. J Feline Med Surg 2007; 9(1): 51-55. PMid:17241806. http://dx.doi. org/10.1016/j.jfms.2006.08.006.

Yang Y, Liang H. Prevalence and risk factors of intestinal parasites in cats from China. Biomed Res Int 2015; 2015: 1-6. http://dx.doi. org/10.1155/2015/410721.

Zanzani SA, Gazzonis AL, Scarpa P, Berrilli F, Manfredi MT. Intestinal parasites of owned dogs and cats from metropolitan and micropolitan areas: Prevalence, zoonotic risks and pet owner awareness in Northern Italy. BioMed Res Int 2014; 2014: 1-9. http://dx.doi.org/10.1155/2014/696508.

Zar JH. Biostatistical analysis. 4th ed. New Jersey: Prentice Hall; 1999. $663 \mathrm{p}$. 